\title{
Nová antikoagulancia u fibrilace síní - kdo vítězí?
}

Podle přednášek, které na XXII. výročním sjezdu České kardiologické společnosti v květnu 2014 přednesli v rámci symposia společnosti Boehringer Ingelheim prof. MUDr. Miloš Táborský, CSc., FESC, MBA (I. interní klinika, LF UP a FN Olomouc) jako předsedající a koordinátor diskuse, prof. MUDr. Aleš Linhart, DrSc. (II. interní klinika, 1. LF UK a VFN, Praha), prof. MUDr. Petr Widimský, DrSc., FESC (Kardiocentrum 3. LF UK a FNKV, Praha) a PharmDr. Josef Suchopár (INFOPHARM, Praha), zpracovala MUDr. Zuzana Zafarová.

Symposium zahájil úvodem do problematiky předsedající prof. Táborský. Uvedl, že fibrilace síní (FS) je nejčastější arytmie, která postihuje $>5 \%$ osob starších 65 let. Pacient s FS je nejvíce ohrožen ischemickou cévní mozkovou přihodou (iCMP) a má vyšší pravděpodobnost, že tato přihoda bude mít trvalé následky nebo že na ni zemře. Antikoagulační léčba u pacientů s FS by měla co nejúčinněji chránit před iCMP při minimalizaci rizika krvácení, zejména mozkového. Se vzrůstajícím skóre $\mathrm{CHA}_{2} \mathrm{DS}_{2}$-VASc stoupá riziko iCMP, které Ize významně snížit podáváním perorální antikoagulační léčby. Vzestup výskytu intrakraniálního krvácení je při porovnání s tímto přínosem, zejména u nových perorálních antikoagulancií (NPA), minimální (obr. 1). Většina iCMP vznikne u pacientů s FS s nedostatečnou nebo chybějící antikoagulační léčbou. Zkrácení doby, po kterou je INR při léčbě warfarinem v terapeutickém rozmezí $2,0-3,0$, pod $60 \%$ významně snižuje jeho účinnost $z$ hlediska prevence CMP. Prof. Táborský svůj úvod k symposiu uzavřel slovy: „Dabigatran zahájil novou éru v prevenci tromboembolických kompli-

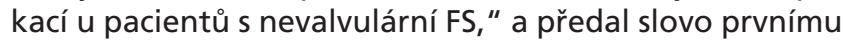
přednášejícímu prof. Linhartovi, jehož prezentace byla zaměřena na pacienty $\mathrm{s} F S \mathrm{v}$ nízkém riziku a v primární prevenci CMP.

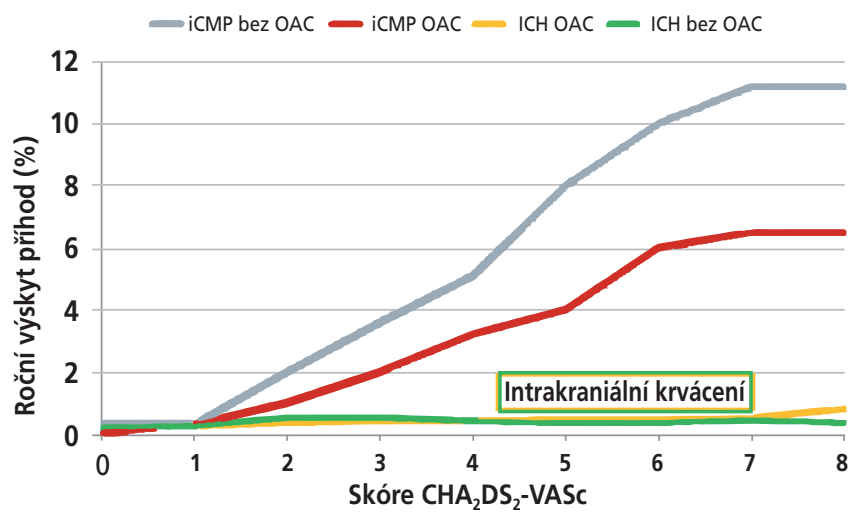

iCMP - ischemická cévní mozková príhoda; ICH - intrakraniální krvácení; OAC - perorální antikoagulancia.

L. Friberg, et al., Swedish Atrial Fibrillation Cohort Study, Circulation (2012). (182 678 pacientů sledováno 1,5 roku)

Obr. 1 - Srovnání incidence iCMP a intrakraniálního krvácení u pacientů s FS dle uživání perorálních antikoagulancií v závislosti na skóre $\mathrm{CHA}_{2} \mathrm{DS}_{2}$-VASc

\begin{tabular}{|c|c|c|c|}
\hline & RE-LY [1] & ROCKET AF ${ }^{[2]}$ & ARISTOTLE ${ }^{[3]}$ \\
\hline \multicolumn{4}{|l|}{ Skóre $\mathrm{CHADS}_{2}(\%)$} \\
\hline $0-1$ & (32) & $<1$ & (34) \\
\hline 2 & 36 & 13 & 36 \\
\hline$\geq 3$ & 32 & 86 & 30 \\
\hline \multicolumn{4}{|l|}{ Rizikové faktory (\%) } \\
\hline Průměrný věk (roky) & 71,5 & 73 & 70 \\
\hline EFLK $\leq 35 *-40 \%$ & 32 & $63^{*}$ & 35 \\
\hline Hypertenze & 79 & 90 & 87 \\
\hline Diabetes mellitus & 23 & 40 & 25 \\
\hline CMP, TIA, SE v anamnéze & 20 & 55 & 19 \\
\hline
\end{tabular}

[1] S.J. Conolly, et al., New England Journal of Medicine 361 (2009) 1139-1151; [2] M.R. Patel, et al., New England Journal of Medicine 365 (2011) 883-891;

[3] C.B. Granger, et al., New England Journal of Medicine 365 (2011) 981-992.

Obr. 2 - Studie RE-LY zahrnovala také pacienty s FS s nízkým rizikem.

\section{Podávání dabigatranu je přínosem i pro nemocné s FS s nízkým rizikem nebo s renální insuficiencí}

Podle doporučených postupů z roku 2012 má být antikoagulační léčba zvážena u všech nemocných s FS se skóre $\mathrm{CHA}_{2} \mathrm{DS}_{2}-\mathrm{VASc} \geq 1$ po posouzení rizika krvácení. Doporučen je warfarin s cílovým INR 2-3, dabigatran, rivaroxaban nebo apixaban. U žen do 65 let s FS, kde je jediným rizikovým faktorem pohlaví, není antikoagulační léčba nezbytně nutná. Jak uvedl prof. Linhart, bylo prokázáno, že se zvyšujícím se skóre CHADS 2 roste riziko cévních mozkových príhod (CMP)/systémové embolie (SE) a vaskulární mortality, ale i riziko krvácení. Potvrzují to údaje ze studie RE-LY, do které byli randomizováni i pacienti s nízkým rizikem (obr. 2).

Pacienti s nízkým skóre $\mathrm{CHADS}_{2}$ zde měli nejnižší riziko CMP/TIA, ale i krvácení. Analýza podskupin ze studie RE-LY ukázala, že výsledky u pacientů se skóre CHADS $_{2}$ 0-1 jsou konzistentní $s$ výsledky celé studie. Pokud jsou u pacientů se skóre $\mathrm{CHADS}_{2}=1$ zohledněny další rizikové faktory zahrnuté do skóre $\mathrm{CHA}_{2} \mathrm{DS}_{2}$-VASc, má $74 \%$ $z$ nich $\mathrm{CHA}_{2} \mathrm{DS}_{2}-\mathrm{VASC} \geq 2$. Subanalýza studie RE-LY dle skóre $\mathrm{CHA}_{2} \mathrm{DS}_{2}$-VASc prokázala, že výhody dabigatranu jsou zachovány bez ohledu na rizikovost pacienta. Jak shrnul prof. Linhart, "CHADS, ve srovnání s $\mathrm{CHA}_{2} \mathrm{DS}_{2}$-VASC 


\begin{tabular}{|l|c|c|}
\hline & $\begin{array}{c}\text { Dabigatran } \\
110 \mathrm{mg} 2 \times \text { denně }\end{array}$ & $\begin{array}{c}\text { Dabigatran } \\
150 \mathrm{mg} 2 \times \text { denně }\end{array}$ \\
\hline $\begin{array}{l}\text { TTR (celková studijní } \\
\text { populace) }\end{array}$ & \multicolumn{2}{|c|}{$64 \%$} \\
\hline Počet pacientů & 4819 & 4843 \\
\hline \multicolumn{3}{|c|}{ Účinnost } \\
\hline CMP/SE & $\mathrm{NI}$ & $40 \%$ \\
\hline CMP & $\mathrm{NI}$ & $42 \%$ \\
\hline $\begin{array}{l}\text { Ischemická CMP nebo } \\
\text { neznámé př́činy }\end{array}$ & $\mathrm{NI}$ & $34 \%$ \\
\hline Hemoragická CMP & $56 \%$ & $75 \%$ \\
\hline Celková mortalita & $\mathrm{NI}$ & $14 \%$ \\
\hline Vaskulární mortalita & $\mathrm{NI}$ & $20 \%$ \\
\hline \multicolumn{2}{|c|}{ Bezpečnost } \\
\hline Závažné krvácení & $34 \%$ & $\mathrm{NI}$ \\
\hline $\begin{array}{l}\text { Intrakraniální } \\
\text { krvácení }\end{array}$ & $80 \%$ & $57 \%$ \\
\hline
\end{tabular}

H.C. Diener, et al., Lancet Neurology 9 (2010) 1157-1163.

Obr. 3 - Dabigatran prokázal výhody oproti warfarinu i v primární prevenci CMP/SE. Porovnání sledovaných parametrů u dabigatranu s warfarinem u pacientů bez CMP v anamnéze při vstupu do studie. $\mathrm{NI}$ - non-inferiorita; \% - snížení relativního rizika; zelené pozadí superiorita.

není dostatečným skórovacím nástrojem pro identifikaci nemocných s velmi nízkým rizikem. I nemocní s nízkým rizikem mají profit z podávání dabigatranu." Naprostá většina těchto nemocných užívá antikoagulační léčbu z důvodu primární prevence CMP, což potvrdilo i hlasování v úvodu symposia, kdy 76 \% př́tomných uvedlo, že těchto pacientů mají ve své péči nejméně $80 \%$. U této populace pacientů prokázal dabigatran $150 \mathrm{mg}$ dvakrát denně významně vyšší účinnost ve snížení rizika iCMP i ostatních klíčových ukazatelů účinnosti v porovnání s warfarinem (obr. 3).

Na závěr prof. Linhart připomněl, že obě skóre opomíjejí mezi rizikovými faktory tromboembolie renální dysfunkci. Přitom pacienti s glomerulární filtrací (eGFR) $<60 \mathrm{ml} / \mathrm{min}$ mají významně vyšší riziko CMP/TIA/SE. Z výsledků subanalýzy studie RE-LY vyplývá, že dabigatran 150 mg 2x denně snižuje toto riziko statisticky významně $i$ u nemocných $s$ eGFR $<80 \mathrm{ml} / \mathrm{min} i<50 \mathrm{ml} / \mathrm{min}$. Podávání dabigatranu při eGFR $<30 \mathrm{ml} / \mathrm{min}$ není indikováno.

\section{Podávání dabigatranu je přínosem i pro pacienty s FS, kteří současně trpí ICHS}

Kardiologové často stojí před situací, jak léčit pacienty s FS a akutním koronárním syndromem (AKS) nebo ischemickou chorobou srdeční (ICHS). Toto téma se pokusil ve své přednášce ozřejmit prof. Widimský. Připomněl, že evropské postupy pro léčbu pacientů s FS léčených NPA, u kterých dojde $k$ infarktu myokardu (IM), doporučují léčbu NPA přerušit a podat injekční antikoagulans. Léčbu NPA je vhodné zahájit, jakmile odezní účinek injekčního antikoagulancia. Při propuštění pacienta z nemocnice a během jednoho roku po IM je nutný individuální přístup, který vychází z rizikových skóre ( $\left.\mathrm{CHA}_{2} \mathrm{DS}_{2}-\mathrm{VASc}, \mathrm{HAS}-\mathrm{BLED}\right)$. Vhodnou kombinací může být clopidogrel s warfarinem, u pacientů s nízkým skóre je alternativou přechodná duální protidestičková léčba. Při elektivní perkutánní koronární intervenci (PCI) u pacientů s FS léčených NPA doporučují evropské postupy přerušit podávání NPA a $\mathrm{PCI}$ provést 12-24 hodin po poslední dávce. Periprocedurálně se podává heparin, kyselina acetylsalicylová, clopidogrel a upřednostňuje se kovový stent. Léčba clopidogrelem se ukončí asi po jednom měsíci. Perorální antikoagulaci je doporučeno opět zahájit před propuštěním z nemocnice v prípadě vysokého skóre $\mathrm{CHA}_{2} \mathrm{DS}_{2}-\mathrm{VASc}$, u pacientů s nízkým skóre za jeden měsíc.

Dále se prof. Widimský věnoval vlivu podávání NPA a warfarinu u pacientů s FS na incidenci IM. Upozornil, že nevýznamně větší výskyt IM ve studii RE-LY u pacientů s dabigatranem v porovnání s warfarinem převáží významně lepší celkový klinický přínos dabigatranu 2x 150 mg. Subanalýza této studie navíc ukázala, že přínos dabigatranu oproti warfarinu je srovnatelný u nemocných s anamnézou/bez anamnézy IM či ICHS. Výskyt IM v klinických studiích s NPA u pacientů s FS (RE-LY, ROCKET-AF, ARISTOTLE) je srovnatelný s warfarinem a pohybuje se od 0,61 \% (warfarin ve studii ARISTOTLE) po 1,1 \% (warfarin ve studii ROCKET-AF). Metaanalýza 12 randomizovaných studií s NPA zahrnujících téměř 55000 pacientů prokázala prínos této léčby oproti antagonistům vitaminu $\mathrm{K}$ (VKA) z hlediska celkové i kardiovaskulární mortality, CMP/SE, závažných a intrakraniálních krvácení a žádný rozdíl ve výskytu IM. Bezpečnost NPA z hlediska incidence IM dokládají i výsledky prospektivní dánské studie v podmínkách reálné praxe (téměř 14000 pacientů sledovaných 14 měsíců), která ukázala významný pokles adjustované mortality, ale také nižší incidenci IM u obou dávek dabigatranu v porovnání s warfarinem. $V$ současné době začíná celosvětová studie RE-DUAL PCI, jejímž cílem je ozřejmit optimální dlouhodobou antitrombotickou léčbu pro nemocné s FS podstupující PCI. Je žrejmé, že současné podávání antiagregační léčby s NPA významně zvyšuje riziko krvácení (stejně jako kombinace warfarinu s protidestičkovou léčbou). Jedinou studií, která hodnotila trojkombinační léčbu s NPA, byla RE-LY. Ukázala, že protidestičková léčba zvyšuje riziko závažného krvácení při kombinaci s jakýmkoliv perorálním antikoagulačním

\section{Pradaxa $110 \mathrm{mg}$ dvakrát denně}

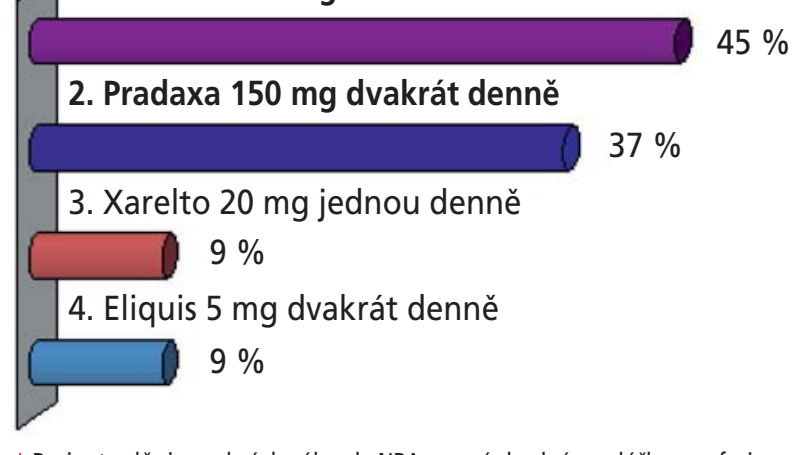

* Pacient splňuje podmínky úhrady NPA - není vhodný pro léčbu warfarinem

Obr. 4 - Jaké nové antikoagulans v kombinaci s duální/monoantiagregací doporučujete pacientům* $s$ fibrilací síní poté, co podstoupí PCI pro AKS? - Výsledky hlasování účastníků symposia. 


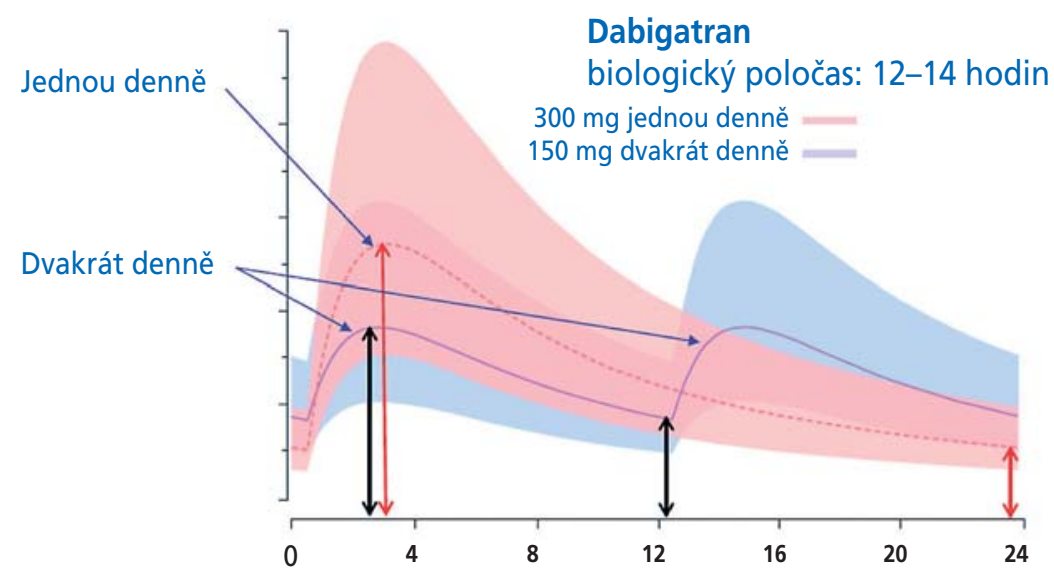

Obr. 5 - Kolísání plazmatických koncentrací při biologickém poločase 12-14 hodin při podávání dabigatranu jednou a dvakrát denně

lékem. Nejnižší absolutní riziko bylo zjištěno u dabigatranu dvakrát denně 110 mg. Při interaktivním hlasování odpovědělo na otázku: „Jaké nové antikoagulans v kombinaci s duální/monoantiagregací doporučujete pacientům s FS poté, co podstoupí PCI pro AKS?" 82 \% účastníků symposia „dabigatran" (z toho $45 \%$ v dávce $110 \mathrm{mg}$ dvakrát denně a $37 \% 150$ mg dvakrát denně) (obr. 4). Jak řekl prof. Widimský: „Výhodou dvou dostupných dávek dabigatranu je flexibilita léčby, kterou Ize přizpůsobit konkrétnímu riziku a prípadně i preferenci pacientů." Zdůraznil, že přednosti obou dávek dabigatranu oproti warfarinu jsou zachovány i u nemocných léčených současně protidestičkovými léky a že $v$ této kombinaci je absolutní riziko krvácení nejnižší u dabigatranu 110 mg.

\section{Lékové interakce u NPA jsou predikovatelné}

Pacienti s FS často z důvodu dalších komorbidit užívají více léků. Je proto důležité znát klinický význam interakcí s NPA. Této problematice se na symposiu věnoval PharmDr. Suchopár.

Ukázal průnik dat, která jsou dostupná pro lékové interakce NPA a jejich klinický význam. Upozornil, že v této souvislosti může rovněž hrát významnou roli délka plazmatického poločasu ve vztahu k četnosti dávkování. Při hodnocení průběhu plazmatických koncentrací v čase je při podávání jedné (dvojnásobné) dávky dosahováno vždy vyšších koncentrací, podá-li se tato dávka jednou denně ve srovnání s podáváním rozdělených (polovičních) dávek v odstupu přibližně 12 hodin. Vzhledem $k$ tomu, že některé nežádoucí účinky NPA jsou závislé na výši plaz- matických koncentrací, je vysoce pravděpodobné, že postup založený na podávání dvou dílčích dávek bude bezpečnější. Vedle toho tak bude zajištěna menší fluktuace plazmatických koncentrací, která není u léčiv, jako jsou antikoagulancia, výhodná (obr. 5).

U všech NPA jsou lékové interakce v porovnání s warfarinem lépe predikovatelné. Nejjednodušší je situace u dabigatranu, který vykazuje interakce pouze na úrovni jednoho transporteru a na jednom místě (střevní sliznice) a tato účinná látka není na rozdíl od ostatních NPA substrátem CYP450 ani jiných efluxních přenašečů.

\section{Závěr}

Symposium odpovědělo na otázku: Nová antikoagulancia u FS - kdo vítězí? Vítězí pacient! Ukázalo, že v péči kardiologů/internistů je většina pacientů s FS v primární prevenci CMP/TIA. Připomnělo, že existují data - výsledky studie RE-LY s dabigatranem - u pacientů s FS s nízkým rizikem, kteří v ambulancích lékařů převažují. Neopomnělo ani pacienty s FS s ICHS, u nichž byl prokázán srovnatelný prrínos dabigatranu. Upozornilo i na problematiku lékových interakcí u pacientů s komorbiditami. Hlavním cílem antikoagulační léčby je, aby u pacienta s FS k mozkové příhodě vůbec nedošlo, tedy aby se v primární prevenci podávala co nejúčinnější terapie. Díky NPA, jejichž prvním zástupcem se roku 2011 stal dabigatran etexilát, má pacient s FS větší šanci, že neprodělá iCMP, a to při výrazně nižším riziku zejména mozkového krvácení než u VKA. 